\title{
Thermostability of Probiotics and Their $\alpha$-Galactosidases and the Potential for Bean Products
}

\author{
Xiaoli Liu, ${ }^{1}$ Claude P. Champagne, ${ }^{2}$ Byong H. Lee, ${ }^{2,3}$ Joyce I. Boye, ${ }^{2}$ and Michel Casgrain ${ }^{4}$ \\ ${ }^{1}$ Institute of Agro-Product Processing, Jiangsu Academy of Agricultural Sciences, Nanjing 210014, China \\ ${ }^{2}$ Agriculture and Agri-Food Canada, Food Research and Development Centre, 3600 Casavant O. Saint-Hyacinthe, QC, \\ Canada J2S 8E3 \\ ${ }^{3}$ School of Biotechnology, Jiangnan University, Wuxi 214122, China \\ ${ }^{4}$ Bonduelle North America, 540, Chemin des Patriotes, Saint-Denis-sur-Richelieu, QC, Canada J0H 1 KO
}

Correspondence should be addressed to Claude P. Champagne; claude.champagne@agr.gc.ca

Received 4 November 2013; Revised 8 January 2014; Accepted 10 January 2014; Published 18 February 2014

Academic Editor: Gabriel A. Monteiro

Copyright (C) 2014 Xiaoli Liu et al. This is an open access article distributed under the Creative Commons Attribution License, which permits unrestricted use, distribution, and reproduction in any medium, provided the original work is properly cited.

\begin{abstract}
Soybeans and other pulses contain oligosaccharides which may cause intestinal disturbances such as flatulence. This study was undertaken to investigate $\alpha$-galactosidase-producing probiotics added to frozen foods which can survive warming treatments used in thawing and consumption of the pulses. The maximum $\alpha$-galactosidase activity (1.26 U/mg protein) was found in Bifidobacterium breve S46. Lactobacillus casei had the highest $\alpha$-galactosidase thermostability among the various strains, with $D$ values of 35,29 , and 9.3 minutes at $50^{\circ} \mathrm{C}, 55^{\circ} \mathrm{C}$, and $60^{\circ} \mathrm{C}$, respectively. The enzyme activity was less affected than viable cells by heating. However, the $D$ values of two bacterial enzymes were lower than those of three commercial $\alpha$-galactosidase-containing products. Freshly grown cells and their enzymes were more stable than the rehydrated cultures and their enzymes. Practical Application. Enzymes and cultures can be added to foods in order to enhance the digestibility of carbohydrates in the gastrointestinal tract. However since many foods are warmed, it is important that the thermostability of the enzymes be assessed. This paper provides data on the stability of $\alpha$-galactosidase, which could potentially be added to food matrices containing stachyose or raffinose, such as beans.
\end{abstract}

\section{Introduction}

There is an increasing demand of nondairy applications of probiotic bacteria $[1,2]$ which indicate much interest by the manufacturers to use fruits and vegetables as carriers of probiotic bacteria. These data suggest that there is considerable global interest in the development and marketing of the vegetable-bean functional probiotic food.

Soybean and many other pulses are an excellent food source due to their high amounts of either dietary fibers, proteins, or micronutrients and phytochemicals $[3,4]$. However, the consumption of soybean and legume products has been somewhat limited because of intestinal disturbances such as flatulence, which is caused by the presence of oligosaccharides. Oligosaccharides in beans, such as raffinose and stachyose, which are nondigestible and not assimilated in the small intestine by the human GI enzymes, are fermented by the microbiota and thus responsible for flatulence $[5,6]$.
Therefore, removal of oligosaccharides from beans could be an important factor in improving their consumption level [7].

Some studies have shown that adding probiotics to pulse products can indeed reduce gastrointestinal discomfort due to gas $[5,8,9]$. However, these studies were carried out in products which had fresh probiotic cultures and which had not undergone processing steps. Many processing, storage, and warming parameters are detrimental to cell viability and enzyme stability and, therefore, present a challenge in the development of probiotic or enzyme-containing legume products. Thus, heating at high temperatures such as those used in blanching, canning, or "stir-fry" cooking is unthinkable for probiotics because temperatures are above $80^{\circ} \mathrm{C}$, which would kill the cells. However, food products are increasingly marketed frozen and are then warmed with microwave units before consumption $[10,11]$. It is unknown to what extent probiotics or their $\alpha$-galactosidases can survive warming temperatures which would reach up to $60^{\circ} \mathrm{C}$. 
The aim of the present study was to evaluate the effects of moderate heat treatments (simulating warming) on probiotic bacteria and their $\alpha$-galactosidases, in order to ascertain the potential use of probiotics as suppliers of $\alpha$-galactosidase in processed pulse-based foods.

\section{Materials and Methods}

2.1. Microorganisms and Culturing. Stock cultures of Lactobacillus rhamnosus 910, Lactobacillus casei $\mathrm{CLbBCV}_{1}$, and Bifidobacterium breve S 46 were kept at $-80^{\circ} \mathrm{C}$ in $20 \%$ glycerol. Bifidobacterium longum R0175 was obtained from Lallemand Health Solutions Inc. (Montréal, QC, Canada) in a freezedried form.

With the frozen strains, $1 \mathrm{~mL}$ stock cultures were thawed at room temperature and inoculated into $100 \mathrm{~mL}$ freshly sterilized MRS (Difco, USA) broth supplemented with $0.05 \%$ (w/v) L-cysteine hydrochloride (Cys). With the freeze-dried cultures, $1 \mathrm{~g}$ of free-cell powder was added into $9 \mathrm{~mL}$ rehydration medium ( $1.5 \mathrm{~g}$ peptone, $1 \mathrm{~g}$ tryptone, $0.5 \mathrm{~g}$ meat extract, $100 \mathrm{~mL}$ water) and incubated for $15 \mathrm{~min}$ at $37^{\circ} \mathrm{C}$ after vortexing for $10 \mathrm{sec}$. After diluting the cell suspension by adding $1 \mathrm{~mL}$ to $9 \mathrm{~mL} 0.1 \%(\mathrm{w} / \mathrm{v})$ sterile peptone water, $1 \mathrm{~mL}$ diluted suspension was inoculated into $100 \mathrm{~mL}$ MRS-Cys broth. The cell suspension was then incubated at $37^{\circ} \mathrm{C}$ in an anaerobic incubator $\left(85 \% \mathrm{~N}_{2}, 10 \% \mathrm{H}_{2}\right.$, and $\left.5 \% \mathrm{CO}_{2}\right)$ until $\mathrm{pH}$ between 4.3 and 4.5 was reached. The incubation time varied slightly between strains but was approximately $16 \mathrm{~h}$.

2.2. Enzymes and Reagents. Three commercial sources of $\alpha$ galactosidases were purchased from the market and analysed: Nutriteck Alpha-Galactosidase (Nutriteck, Chateauguay, QC, Canada), Beano (GlaxoSmithKline, Moon Township, PA, USA), and Digestive Advantage Gas Defense Formula (Ganeden Biotech, Mayfield Heights, OH, USA). $p$-Nitrophenyl- $\alpha$ D-galactopyranoside (pNPG), $p$-nitrophenol, bovine serum albumin, and Bradford reagent kit were purchased from Sigma (Oakville, ON, Canada).

2.3. Enzyme Extraction. Bacterial cells were centrifuged at $7,000 \mathrm{~g}$ for $20 \mathrm{~min}$ at $4^{\circ} \mathrm{C}$. After discarding the supernatant, the cell pellet was washed in $10 \mathrm{~mL}$ of $50 \mathrm{mM} \mathrm{Na}$ phosphate (pH 6.0) twice. Finally the cells were resuspended in $10 \mathrm{~mL}$ of the same buffer. The cells were incubated in an ice bath $\left(4^{\circ} \mathrm{C}\right)$ and sonicated using a Misonix sonicator S4000 (Newtown, CT 06470 , USA), with an output amplitude level of 6 , and the total process time of 16 min was carried out in 4 cycles of 3 minutes on and 1 minute off. The cell debris was removed by centrifugation at $14,000 \mathrm{~g}$ for $20 \mathrm{~min}$ at $4^{\circ} \mathrm{C}$. The supernatant was used as a crude enzyme extract.

2.4. Enzyme Assay. $\alpha$-Galactosidases activity was assayed according to the modified method of Donkor et al. [12].50 $\mu \mathrm{L}$ enzyme extract was mixed with $150 \mu \mathrm{L} 2 \%$ (w/v) pNPG and incubated at $37^{\circ} \mathrm{C}$ for $20 \mathrm{~min}$. The reaction was stopped by addition of $200 \mu \mathrm{L} 0.1 \mathrm{~mol} \mathrm{~L}^{-1}$ sodium carbonate solution. The amount of $p$-nitrophenol released was measured with a spectrophotometer at $420 \mathrm{~nm}$. One unit of enzyme activity was defined as the amount of enzyme that released one $\mu \mathrm{mol}$ p-nitrophenol per min under the assay conditions.

2.5. Determination of Protein Concentration. An aliquot $(0.1 \mathrm{~mL})$ of the crude enzyme and $3 \mathrm{~mL}$ of the Bradford reagent were vortexed for $5 \mathrm{sec}$ to mix thoroughly and incubated at room temperature for $30 \mathrm{~min}$, followed by absorbance measurement at $595 \mathrm{~nm}$. Bovine serum albumin (Sigma) was used to prepare the standard curve.

2.6. Effect of Temperature on Viability of Cell. Bacterial cultures in MRS were incubated using an Eppendorf Mastercycler PCR system (Eppendorf Scientific, Westbury, NY, USA) with high heating speed set at different temperatures in the range of $50-60^{\circ} \mathrm{C}$. Cultures $(0.15 \mathrm{~mL})$ were placed in Eppendorf tubes, removed at specific time points, and immediately cooled in an ice bath, and then aliquots of $0.1 \mathrm{~mL}$ cell suspension were diluted with $9.9 \mathrm{~mL}$ of $0.1 \%$ sterile peptone water. In the first dilution tube we carried out a high-shear homogenization step with an Omni TH unit (Marietta GA, USA) equipped with Omni Tip plastic probe at 27000 RPM for $30 \mathrm{sec}$. The subsequent dilutions were carried out in $0.1 \%$ sterile peptone water with blending with a vortex unit for $5 \mathrm{sec}$. The dilutions were plated on MRS agar and incubated at $37^{\circ} \mathrm{C}$ in an anaerobic incubator $\left(85 \% \mathrm{~N}_{2}, 10 \% \mathrm{H}_{2}\right.$, and $5 \% \mathrm{CO}_{2}$ ). The $D$ values (heating time required to generate a $1 \log$ reduction on viable counts) were determined for each temperature and served to calculate the $Z$ value (increase in temperature required to reduce the $D$ value by a factor of ten).

In one series of assays with $B$. longum R0175, the cell pellet obtained after centrifugation was resuspended in $50 \mathrm{mM} \mathrm{Na}$ phosphate $(\mathrm{pH}$ 6.0) and this cell suspension was exposed to the $50-60^{\circ} \mathrm{C}$ thermal treatment instead of the $\mathrm{pH} 4.5$ culture in the MRS broth. This treatment enabled examination of the effect of the medium, and particularly $\mathrm{pH}$, on the thermostability of the cultures.

In another series of assays, instead of using the fresh liquid culture obtained after $16 \mathrm{~h}$ incubation, a B. longum R0175 cell suspension was treated at $50-60^{\circ} \mathrm{C}$ immediately after being rehydrated. The goal of this treatment was to evaluate the effect of the method of preparation of the cell suspension on thermostability.

2.7. Effect of Temperature on the Stability of Enzyme Preparation. Known units of enzyme solutions were prepared by rehydrating the commercial powders into $50 \mathrm{mM} \mathrm{Na}$ phosphate ( $\mathrm{pH}$ 6.0) at room temperature. If necessary, further dilutions were carried out in $50 \mathrm{mM} \mathrm{Na}$ phosphate ( $\mathrm{pH} 6.0$ ). The thermostability assays were carried out by incubating the solutions at different temperatures in the range of $50-60^{\circ} \mathrm{C}$. The same method and equipment as were used to evaluate the effect of heating on the CFU was applied to the enzymes samples. The activity of untreated enzyme was defined as $100 \%$.

2.8. Statistical Analysis. All the experiments were carried out three times independently, in order to ascertain the reproducibility of the results. The data presented are the average 
TABLE 1: Growth and $\alpha$-galactosidase activities of the probiotic strains.

\begin{tabular}{lcccc}
\hline Strain & Activity $(\mathrm{U} / \mathrm{mL})$ & Population $(\mathrm{CFU} / \mathrm{mL})$ & Protein $(\mathrm{mg} / \mathrm{mL})$ & Specific activity $(\mathrm{U} / \mathrm{mg}$ protein $)$ \\
\hline Lb. rhamnosus 910 & 0.21 & $2.03 \times 10^{9}$ & 4.58 & $0.04^{\mathrm{a}}$ \\
Lb. casei CLbBCV & 0.20 & $1.67 \times 10^{9}$ & 3.82 & $0.04^{\mathrm{a}}$ \\
B. breve S46 & 2.20 & $8.50 \times 10^{9}$ & 1.79 & $1.26^{\mathrm{c}}$ \\
B. longum R0175 & 0.48 & $1.64 \times 10^{9}$ & 3.17 & $0.16^{\mathrm{b}}$ \\
\hline
\end{tabular}

${ }^{a, b, c}$ Values in a given column which are followed by the same letter are not statistically different $(P>0.05)$.

TABLE 2: Thermostability of overnight-grown microbial cultures as viable counts in acidified MRS (pH 4.5).

\begin{tabular}{|c|c|c|c|c|}
\hline \multirow{2}{*}{ Strain } & \multicolumn{3}{|c|}{$D$ value (minutes) } & \multirow{2}{*}{$Z$ value $\left({ }^{\circ} \mathrm{C}\right)$} \\
\hline & $50^{\circ} \mathrm{C}$ & $55^{\circ} \mathrm{C}$ & $60^{\circ} \mathrm{C}$ & \\
\hline Lb. rhamnosus 910 & $81.0 \pm 38.5^{\mathrm{a}}$ & $29.1 \pm 5.9^{\mathrm{a}}$ & $5.8 \pm 0.3^{\mathrm{a}}$ & $9.2 \pm 1.7^{\mathrm{c}}$ \\
\hline Lb. casei CLbBCV1 & $34.9 \pm 4.1^{\mathrm{b}}$ & $29.2 \pm 1.4^{\mathrm{a}}$ & $9.3 \pm 1.9^{\mathrm{b}}$ & $17.4 \pm 1.6^{\mathrm{a}}$ \\
\hline B. breve S46 & $1.80 \pm 0.06^{\mathrm{c}}$ & $0.42 \pm 0.0^{\mathrm{b}}$ & $0.29 \pm 0.01^{c}$ & $12.7 \pm 0.1^{b}$ \\
\hline B. longum R0175 & $1.68 \pm 0.22^{\mathrm{c}}$ & $0.71 \pm 0.01^{b}$ & $0.63 \pm 0.03^{c}$ & $15.4 \pm 0.75^{\mathrm{ab}}$ \\
\hline
\end{tabular}

of the three determinations. Paired $t$-tests and analysis of variance (ANOVA) were carried out with SigmaPlot software.

\section{Results}

3.1. $\alpha$-Galactosidases Activity of Probiotic Strains. The $\alpha$ galactosidases activities in probiotic strains grown in MRS are shown in Table 1 . The organisms exhibited $\alpha$-galactosidase activities at different degrees. Bifidobacterium breve $S 46$ had the highest $\alpha$-galactosidase activity and biomass yield, but $L b$. rhamnosus 910 showed the highest protein yield. Data show that enzyme yield depends on specific cell enzyme activity as well as biomass in the bioreactor.

3.2. Thermostability of the Bacterial Cultures. The $D$ values between 50 and $60^{\circ} \mathrm{C}$ show that the overnight-grown lactobacilli cells in acidified MRS cultures are much more stable than the corresponding bifidobacteria cultures (Table 2). Assuming the product could be cooked or exposed to $60^{\circ} \mathrm{C}$ for $15 \mathrm{~min}$ before being eaten, it can be predicted that such a situation would result in a loss of approximately 95\% of the viable cells. In the case of overheating of the product, $L b$. case $i$ appears to be the most appropriate culture because its $Z$ value was higher than that of $L b$. rhamnosus. The medium in which the cells are suspended during heating had a significant effect on the viability losses. Thus, when an overnight-grown B. longum R0175 culture in MRS at $\mathrm{pH} 4.5$ was centrifuged and cells were resuspended in a $\mathrm{pH} 6.0$ phosphate buffer, the $D$ values were almost 10 times higher (Table 3 ) than those of the acid MRS (Table 2).

Under industrial conditions, as most food processors do not have fermentation vats designed to prepare fresh overnight cultures, they would add frozen or dried cells directly to the food matrix [13]. As a result, when inoculating a frozen food product, the cells would rehydrate during thawing and warming. Therefore, the stability of freshly rehydrated cells was compared to that of the overnight-grown cultures. Data show that the $D$ values of $B$. longum R0175 were about
$20 \%$ lower in the freshly rehydrated cultures as compared to liquid-overnight cultures (Table 3). Therefore, one could expect slightly lower stability in commercial products in which freeze-dried products are directly added.

3.3. Thermostability of the Enzymes. The commercial products had similar $Z$ patterns for their $\alpha$-Gal but showed significant differences with respect to $D$ values (Table 4 ). The data provided by the suppliers state that the organism producing the $\alpha$-Gal is Aspergillus niger which would normally result in similar results. The differences between Ganeden and other products might be due to the presence of a Bacillus coagulans probiotic in one of the products or to different $A$. niger strains. Also bulking and stabilizer agents added into each commercial enzyme may have affected the results.

There were much greater variations in the thermostability properties of the bacterial $\alpha$-Gals than in the commercial ones. The $Z$ values of the different probiotic strains were all statistically different (Table 4).

In similar phosphate buffer ( $\mathrm{pH}$ 6.0) medium, $D$ values of the bacterial enzymes (Table 4) were much higher than those of the viable counts (Table 3 ). The $D$ values of three commercial $\alpha$-Gal enzymes were higher than those of the probiotic bacteria (Table 4), presumably because of the fungal sources or spore-bearing Bacillus source of commercial products. Therefore, a greater quantity of $\alpha$-Gal of probiotic bacteria would be needed than that of the commercial enzymes in order to obtain a given $\alpha$-Gal activity after warming. The $Z$ value of the Lb. casei enzyme was slightly higher than that of $L b$. rhamnosus (Table 4). This suggests that $L b$. casei would be a better choice than $L b$. rhamnosus for food enrichment in the case of overheating.

The high stability of the commercial $\alpha$-Gal was expected since Manzanares et al. [14] report a high Aspergillus niger $\alpha$-Gal activity at $50^{\circ} \mathrm{C}$. There are also reports of high $\alpha$-Gal activity at $50^{\circ} \mathrm{C}$ with $\mathrm{Lb}$. fermentum [15]. It was noteworthy that two commercial products had very similar $D$ patterns (Table 4). The Ganeden product contains Bacillus culture 
TABLE 3: Effect of culture preparation method on thermostability of Bifidobacterium longum R0175 cells and $\alpha$-galactosidases in phosphate media at $\mathrm{pH} 6.0$.

\begin{tabular}{|c|c|c|c|c|c|}
\hline \multirow{2}{*}{ Preparation method } & \multirow{2}{*}{ Biological material } & \multicolumn{3}{|c|}{$D$ value (minutes) } & \multirow{2}{*}{$Z$ value $\left({ }^{\circ} \mathrm{C}\right)$} \\
\hline & & $50^{\circ} \mathrm{C}$ & $55^{\circ} \mathrm{C}$ & $60^{\circ} \mathrm{C}$ & \\
\hline \multirow{2}{*}{ Freshly rehydrated } & Cell (CFU) & $16 \pm 2^{\mathrm{a}}$ & $2.4 \pm 0.1^{\mathrm{a}}$ & ND & $5.1 \pm 0.2^{\mathrm{a}}$ \\
\hline & $\alpha$-Galactosidases & $263 \pm 18^{\mathrm{b}}$ & $97 \pm 4^{\mathrm{b}}$ & $52 \pm 4^{\mathrm{a}}$ & $16 \pm 1^{b}$ \\
\hline \multirow{2}{*}{ Liquid-overnight culture } & Cell (CFU) & $19 \pm 3^{\mathrm{a}}$ & $2.8 \pm 0.4^{\mathrm{a}}$ & ND & $5.1 \pm 0.5^{\mathrm{a}}$ \\
\hline & $\alpha$-Galactosidases & $800 \pm 100^{c}$ & $159 \pm 10^{\mathrm{b}}$ & $115 \pm 1^{\mathrm{b}}$ & $12 \pm 1^{\mathrm{b}}$ \\
\hline
\end{tabular}

ND: not determined.

${ }^{\mathrm{a}, \mathrm{b}, \mathrm{c}}$ Values in a given column which are followed by the same letter are not statistically different $(P>0.05)$.

TABLE 4: $D$ and $Z$ values of $\alpha$-galactosidases from overnight-grown strains and commercial products.

\begin{tabular}{|c|c|c|c|c|}
\hline \multirow{2}{*}{ Strain or commercial enzyme } & \multicolumn{3}{|c|}{$D$ value (minutes) } & \multirow{2}{*}{$Z$ value $\left({ }^{\circ} \mathrm{C}\right)$} \\
\hline & $50^{\circ} \mathrm{C}$ & $55^{\circ} \mathrm{C}$ & $60^{\circ} \mathrm{C}$ & \\
\hline Beano & $2070 \pm 289^{\mathrm{a}}$ & $209 \pm 2^{a}$ & $175 \pm 14^{\mathrm{a}}$ & $9.2 \pm 0.7^{\mathrm{cd}}$ \\
\hline Ganaden & $1530 \pm 241^{\mathrm{b}}$ & $170 \pm 9^{\mathrm{b}}$ & $121 \pm 6^{\mathrm{b}}$ & $9.1 \pm 0.6^{\mathrm{cd}}$ \\
\hline Nutriteck & $939 \pm 53^{c}$ & $270 \pm 25^{\mathrm{c}}$ & $96 \pm 1^{c}$ & $10.1 \pm 0.2^{\mathrm{bc}}$ \\
\hline Lactobacillus rhamnosus & $1110 \pm 101^{\mathrm{c}}$ & $170 \pm 12^{\mathrm{b}}$ & $71 \pm 5^{\mathrm{d}}$ & $8.7 \pm 0.6^{\mathrm{d}}$ \\
\hline Lactobacillus casei & $860 \pm 81^{c}$ & $216 \pm 10^{\mathrm{a}}$ & $97 \pm 7^{\mathrm{c}}$ & $10.6 \pm 0.8^{\mathrm{b}}$ \\
\hline Bifidobacterium breve & $1700 \pm 287^{\mathrm{b}}$ & $265 \pm 31^{\mathrm{c}}$ & $6.6 \pm 0.4^{\mathrm{e}}$ & $4.2 \pm 0.2^{\mathrm{e}}$ \\
\hline Bifidobacterium longum & $800 \pm 100^{c}$ & $159 \pm 10^{\mathrm{b}}$ & $115 \pm 1^{b}$ & $12.0 \pm 0.7^{\mathrm{a}}$ \\
\hline
\end{tabular}

$\overline{\mathrm{a}, \mathrm{b}, \mathrm{c}}$ Values in a given column which are followed by the same letter are not statistically different $(P>0.05)$.

as well as a blend of enzymes, which included $\alpha$-Gal. The commercial $\alpha$-Gal is typically obtained from Aspergillus niger. These data suggest that the Ganeden activity appeared to be from the exogenous enzymes. Further studies are needed on the Ganeden product with respect to the potential contribution of the Bacillus coagulans culture to $\alpha$-Gal activity.

\section{Discussion}

This study was conducted in a perspective that probiotics could be added to frozen foods, destined to be warmed in a microwave apparatus, which contain nondigestible oligosaccharides. The ultimate aim of enrichment with probiotics is to reduce gas discomforts following consumption. Preventing intestinal problems linked to low digestion of food carbohydrates has been achieved with yoghurt for a subpopulation that suffers from lactose maldigestion [16]. However, yoghurt is eaten directly and cells are not subjected to heating prior to consumption.

A sizeable portion of frozen foods are not stir-fried but are simply thawed in the bag using microwave units and served directly. In the latter, foods are preferably warmed and tasted at temperatures between 45 and $60^{\circ} \mathrm{C}$ [17-19], but the FDA Food Code specifies that $60^{\circ} \mathrm{C}$ or higher should be used [20]. As a result, thermostability of the bacteria and enzymes was estimated in the $50-60^{\circ} \mathrm{C}$ range in our study.

The inactivation temperature of $\alpha$-galactosidases differed between strains and sources, and this was also noted in the literature. Viana et al. [21] prepared soybean $\alpha$-galactosidases presenting maximal activity at $60^{\circ} \mathrm{C}$, but the enzyme from Talaromyces flavus was inactivated after $5 \mathrm{~h}$ at $60^{\circ} \mathrm{C}$ [22]. Data from this study are in line with the latter [22].
Some legume-containing food blends may have an acid $\mathrm{pH}$, particularly if tomatoes are added. Studies were therefore carried out on the thermostability of probiotics in an acid medium. It is well known that heat resistance of bacterial cells is reduced by low $\mathrm{pH}[23,24]$. Thus, as expected, $B$. longum R0175 cells in acidified MRS ( $\mathrm{pH}$ 4.5) showed a thermal survival rate which was significantly lower than those that had been centrifuged and resuspended in a $\mathrm{pH} 6.0$ PBS medium. These data suggest that manufacturers should preferably add probiotic cultures in a food matrix having a neutral pH when they are to be subsequently heated.

Preparing fresh probiotic cultures at a processing plant requires equipment and specialized personnel. Most food manufacturers might therefore prefer to inoculate concentrated dried cultures from specialized suppliers rather than to produce them at their own plant. Using dried cell cultures in the food industry has the added advantages of improved quality and reproducibility, as well as enhanced microbial safety and health benefits $[25,26]$. However, during manufacturing, cellular damage occur during the freezing and drying processes [27-29]. As a result, many factors will influence viability assessment of bacterial cultures during rehydration and particularly the hydration matrix, temperature, and time [30]. Assays were therefore conducted to ascertain if freshly rehydrated cultures had different sensitivity to subsequent heating than overnight-grown liquid cultures. Data show that the $D$ values of viable counts were lower in the rehydrated culture, but this was not statistically significant. Such was not the case, however, with the enzyme activity. The $\alpha$-Gal of cells which have undergone one transfer (grown overnight) was less sensitive to heating than that of freshly rehydrated cells. It was not ascertained if this was due to sublethal damage the 
freeze-dried cultures possessed or if the fermentation process provided subsequent enhanced resistance to heat stress [3133]. In light of the lower stability of the just-rehydrated culture, processors wishing to carry out direct inoculation in foods which are subsequently heated might find it useful to increase the inoculation level in order to compensate for the increased sensitivity of these cell suspensions upon subsequent warming.

In our study, $D$ value and $Z$ value were used to evaluate the thermostability of probiotic cells and enzymes. According to our results and based on their thermostabilities on viable counts, lactobacilli rather than bifidobacteria should be considered for future assays in heated food products. This is not necessarily the case for $\alpha$-Gal activity, where stability of the Bifidobacterium longum enzyme was as high as that of the lactobacilli. Unfortunately, the thermostability of the $\alpha$-Gal of the probiotics is still lower than that of commercial products. In order to increase the thermostability of the bacteria and their enzymes, studies on microencapsulation need to be carried out.

This study was a necessary "proof of concept" step to ascertain if some probiotics/enzymes could indeed survive a short heating period at $60^{\circ} \mathrm{C}$. It also enabled us to select proper thermoresistant commercial probiotics/enzymes for further testing. Studies are currently under way to assess if the selected dried cultures blended with frozen beans can survive frozen storage $\left(-20^{\circ} \mathrm{C}\right)$ and thawing in a microwave, as well as if there subsequently remains $\alpha$-Gal activity in a simulated gastrointestinal system.

\section{Conflict of Interests}

The authors declare that there is no conflict of interests regarding the publication of this paper.

\section{Acknowledgments}

This study was carried out with financial support from the Pulse Science Cluster, an industry-led research network created under the Canadian Agri-Science Cluster initiative of the Growing Canadian Agri-Innovation. The Jiangsu Government Scholarship of Overseas Studies supported the work of X Liu. The authors thank Yves Raymond, Archana Kumari, Marie-Josée Lemay, Sunghoon Park, and Nancy Guertin for their technical support.

\section{References}

[1] L. Masco, G. Huys, E. de Brandt, R. Temmerman, and J. Swings, "Culture-dependent and culture-independent qualitative analysis of probiotic products claimed to contain bifidobacteria," International Journal of Food Microbiology, vol. 102, no. 2, pp. 221-230, 2005.

[2] F. C. Prado, J. L. Parada, A. Pandey, and C. R. Soccol, "Trends in non-dairy probiotic beverages," Food Research International, vol. 41, no. 2, pp. 111-123, 2008.

[3] S. S. De, "Technology of production of edible flours and protein products from soybean," Agricultural Services Bulletin, vol. 11, pp. 1-158, 1971.
[4] F. Roy, J. I. Boye, and B. K. Simpson, "Bioactive proteins and peptides in pulse crops: pea, chickpea and lentil," Food Research International, vol. 43, no. 2, pp. 432-442, 2010.

[5] J. G. Leblanc, F. Ledue-Clier, M. Bensaada et al., "Ability of Lactobacillus fermentum to overcome host $\alpha$-galactosidase deficiency, as evidenced by reduction of hydrogen excretion in rats consuming soya $\alpha$-galacto-oligosaccharides," BMC Microbiology, vol. 8, article 22, 2008.

[6] C. T. Yamaguishi, C. T. Sanada, P. M. Gouvea et al., "Biotechnological process for producing black bean slurry without stachyose," Food Research International, vol. 42, no. 4, pp. 425429, 2009.

[7] J. P. Machaiah, M. D. Pednekar, and P. Thomas, "Reduction in flatulence factors in mung beans (Vigna radiate) using lowdose gamma-irradiation," Journal of the Science of Food and Agriculture, vol. 79, no. 5, pp. 648-652, 1999.

[8] S. Nobaek, M. L. Johansson, G. Molin, S. Ahrné, and B. Jeppsson, "Alteration of intestinal microflora is associated with reduction in abdominal bloating and pain in patients with irritable bowel syndrome," American Journal of Gastroenterology, vol. 95, no. 5, pp. 1231-1238, 2000.

[9] D. M. Saulnier, S. Kolida, and G. R. Gibson, "Microbiology of the human intestinal tract and approaches for its dietary modulation," Current Pharmaceutical Design, vol. 15, no. 13, pp. 1403-1414, 2009.

[10] J. Boye, F. Zare, and A. Pletch, "Pulse proteins: processing, characterization, functional properties and applications in food and feed," Food Research International, vol. 43, no. 2, pp. 414431,2010

[11] B. K. Tiwari, A. Gowen, and B. Mckenna, Pulse Foods. Processing, Quality and Nutraceutical Applications, Academic Press, New York, NY, USA, 2011.

[12] O. N. Donkor, A. Henriksson, T. Vasiljevic, and N. P. Shah, “ $\alpha$ Galactosidase and proteolytic activities of selected probiotic and dairy cultures in fermented soymilk," Food Chemistry, vol. 104, no. 1, pp. 10-20, 2007.

[13] C. P. Champagne and H. Møllgaard, "Production of probiotic cultures and their addition in fermented foods," in Handbook of Fermented Functional Foods, E. R. Farnworth, Ed., pp. 513-532, CRC Press, Taylor \& Francis, Boca Raton, Fla, USA, 2nd edition, 2008.

[14] P. Manzanares, L. H. de Graaff, and J. Visser, "Characterization of galactosidases from Aspergillus niger: purification of a novel $\alpha$-galactosidase activity," Enzyme and Microbial Technology, vol. 22, no. 5, pp. 383-390, 1998.

[15] E. A. Carrera-Silva, A. Silvestroni, J. G. Leblanc, J. C. Piard, G. S. de Giori, and F. Sesma, "A thermostable $\alpha$-galactosidase from Lactobacillus fermentum CRL722: genetic characterization and main properties," Current Microbiology, vol. 53, no. 5, pp. 374378, 2006.

[16] European Food Safety Authority and EFSA Panel on Dietetic Products, Nutrition and Allergies (NDA), "Scientific opinion on the substantiation of health claims related to live yoghurt cultures and improved lactose digestion (ID 1143, 2976) pursuant to Article 13(1) of Regulation (EC) No 1924/2006," EFSA Journal, vol. 8, no. 10, p. 1763, 2010.

[17] S. Ryynänen, H. Tuorila, and L. Hyvönen, "Perceived temperature effects on microwave heated meals and meal components," Food Service Technology, vol. 1, pp. 141-148, 2001.

[18] S. Ventanas, S. Mustonen, E. Puolanne, and H. Tuorila, "Odour and flavour perception in flavoured model systems: influence of 
sodium chloride, umami compounds and serving temperature," Food Quality and Preference, vol. 21, no. 5, pp. 453-462, 2010.

[19] P. Kähkönen, H. Tuorila, and L. Hyvönen, "Dairy fat content and serving temperature as determinants of sensory and hedonic characteristics in cheese soup," Food Quality and Preference, vol. 6, no. 2, pp. 127-133, 1995.

[20] J. B. Hutson, C. M. Bednar, and J. Kwon, "Effectiveness of serving temperature and packaging on temperature retention of hot and cold foods included in take-out meals," Journal of the American Dieticians Association, vol. 103, supplement 9, pp. 204-205, 2003.

[21] S. F. Viana, V. M. Guimarães, I. José et al., "Hydrolysis of oligosaccharides in soybean flour by soybean $\alpha$-galactosidase," Food Chemistry, vol. 93, no. 4, pp. 665-670, 2005.

[22] P. Simerská, D. Monti, I. Čechová et al., "Induction and characterization of an unusual $\alpha$-D-galactosidase from Talaromyces flavus," Journal of Biotechnology, vol. 128, no. 1, pp. 61-71, 2007.

[23] H. Lee, B. Zhou, H. Feng, and S. E. Martin, "Effect of pH on inactivation of Escherichia coli K12 by sonication, manosonication, thermosonication, and manothermo sonication," Journal of Food Science, vol. 74, no. 4, pp. E191-E198, 2009.

[24] B. M. Corcoran, C. Stanton, G. Fitzgerald, and R. P. Ross, "Life under stress: the probiotic stress response and how it may be manipulated," Current Pharmaceutical Design, vol. 14, no. 14, pp. 1382-1399, 2008.

[25] T. D. Boylston, C. G. Vinderola, H. B. Ghoddusi, and J. A. Reinheimer, "Incorporation of bifidobacteria into cheeses: challenges and rewards," International Dairy Journal, vol. 14, no. 5, pp. 375-387, 2004.

[26] D. Dimitrellou, Y. Kourkoutas, I. M. Banat, R. Marchant, and A. A. Koutinas, "Whey cheese production using freeze-dried kefir culture as a starter," Journal of Applied Microbiology, vol. 103, no. 4, pp. 1170-1183, 2007.

[27] R. R. Ravula and N. P. Shah, "Viability of probiotic bacteria in fermented frozen dairy desserts," Food Australia, vol. 50, no. 3, pp. 136-139, 1998.

[28] C. P. Champagne, N. Gardner, E. Brochu, and Y. Beaulieu, "The freeze-drying of lactic acid bacteria: a review," Canadian Institute of Food Science and Technology Journal, vol. 24, pp. 118128, 1991.

[29] M. Kramer, N. Obermajer, B. B. Matijašić, I. Rogelj, and V. Kmetec, "Quantification of live and dead probiotic bacteria in lyophilised product by real-time PCR and by flow cytometry," Applied Microbiology and Biotechnology, vol. 84, no. 6, pp. 11371147, 2009.

[30] C. P. Champagne, R. P. Ross, M. Saarela, K. F. Hansen, and D. Charalampopoulos, "Recommendations for the viability assessment of probiotics as concentrated cultures and in food matrices," International Journal of Food Microbiology, vol. 149, no. 3, pp. 185-193, 2011.

[31] J. M. Bruno-Barcena, M. A. Azcarate-Peril, and H. M. Hassan, "Role of antioxidant enzymes in bacterial resistance to organic acids," Applied and Environmental Microbiology, vol. 76, no. 9, pp. 2747-2753, 2010.

[32] M. de Angelis and M. Gobbetti, "Environmental stress responses in Lactobacillus: a review," Proteomics, vol. 4, no. 1, pp. 106-122, 2004.

[33] C. Desmond, C. Stanton, G. F. Fitzgerald, K. Collins, and R. P. Ross, "Environmental adaptation of probiotic lactobacilli towards improvement of performance during spray drying," International Dairy Journal, vol. 11, no. 10, pp. 801-808, 2001. 

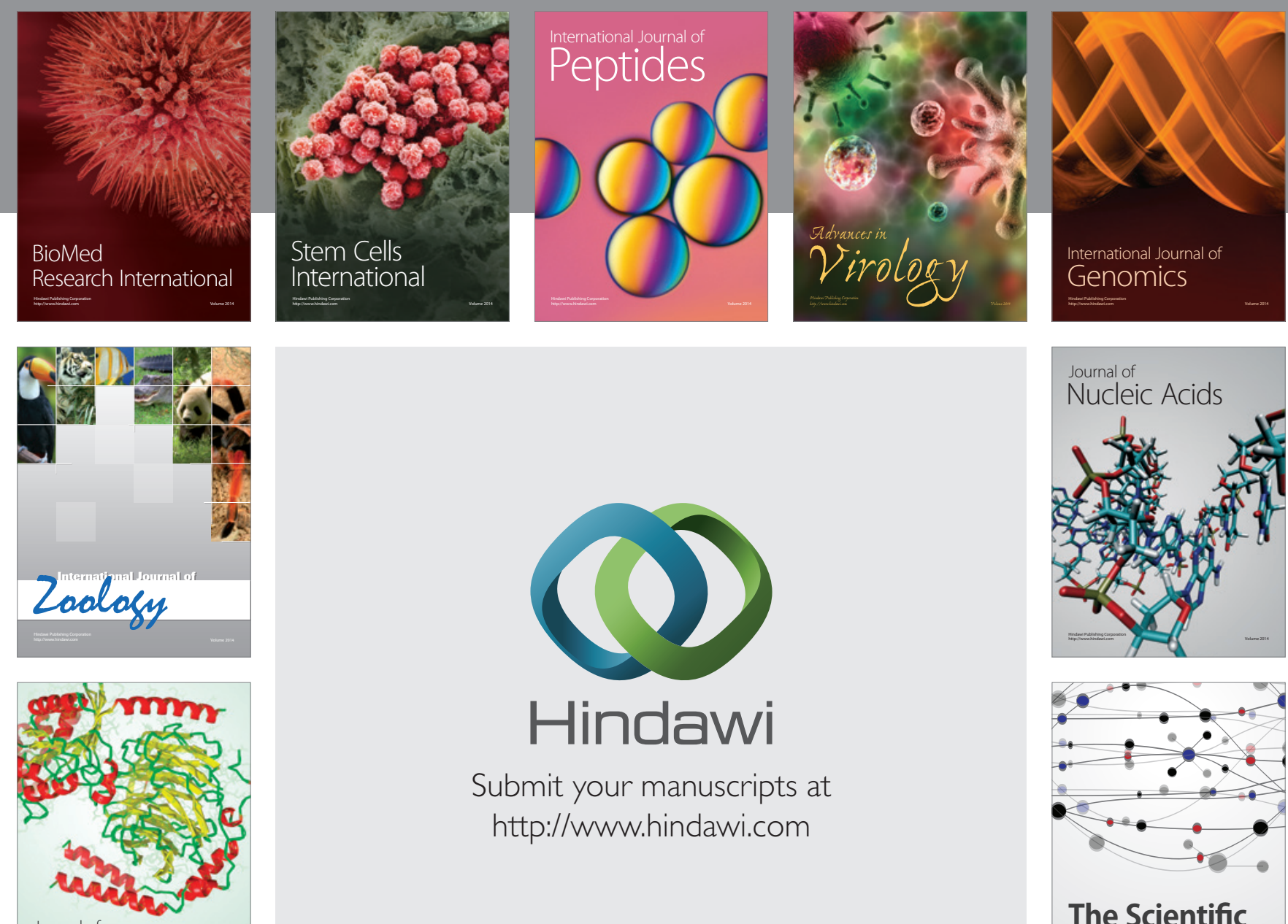

Submit your manuscripts at

http://www.hindawi.com

Journal of
Signal Transduction
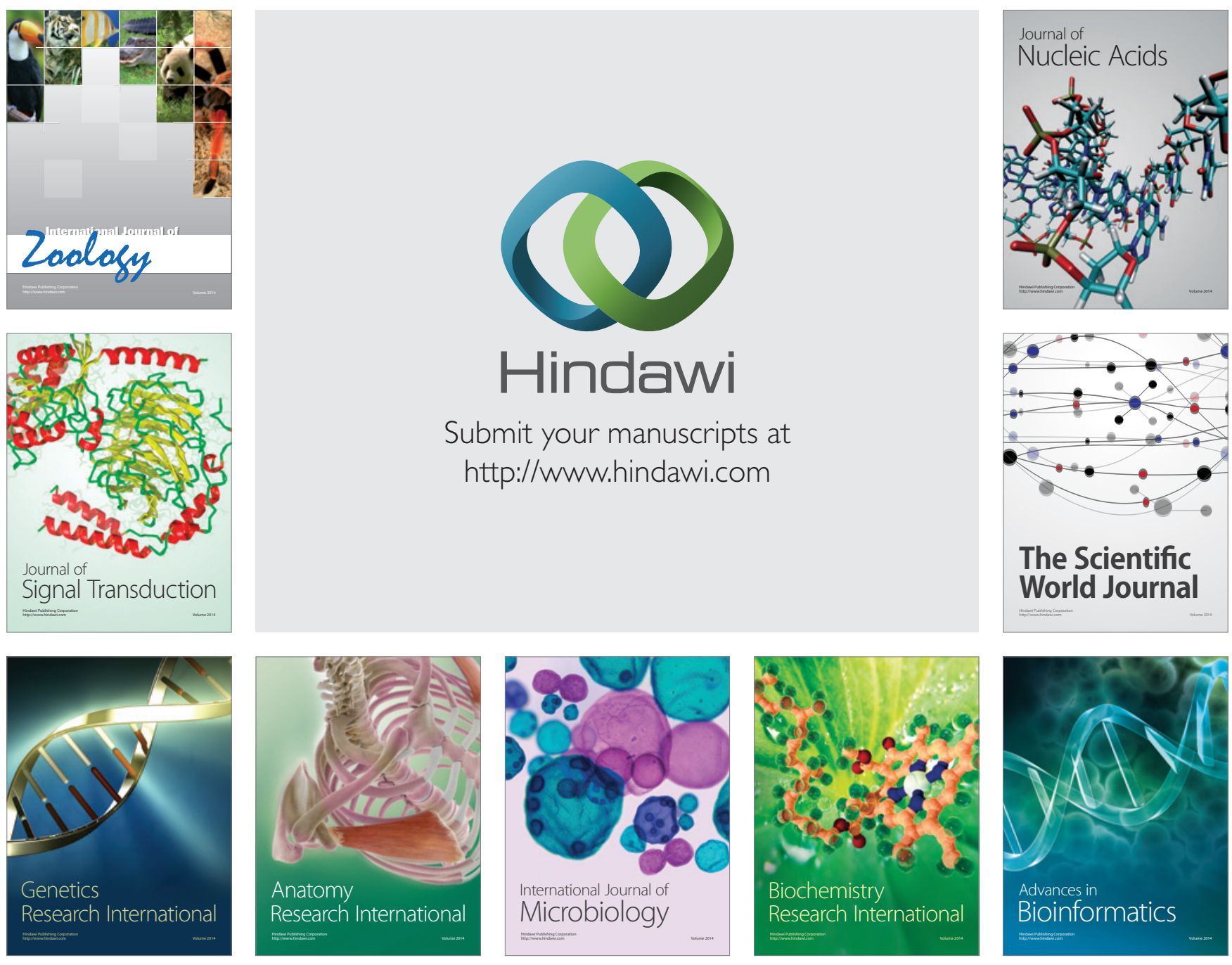

The Scientific World Journal
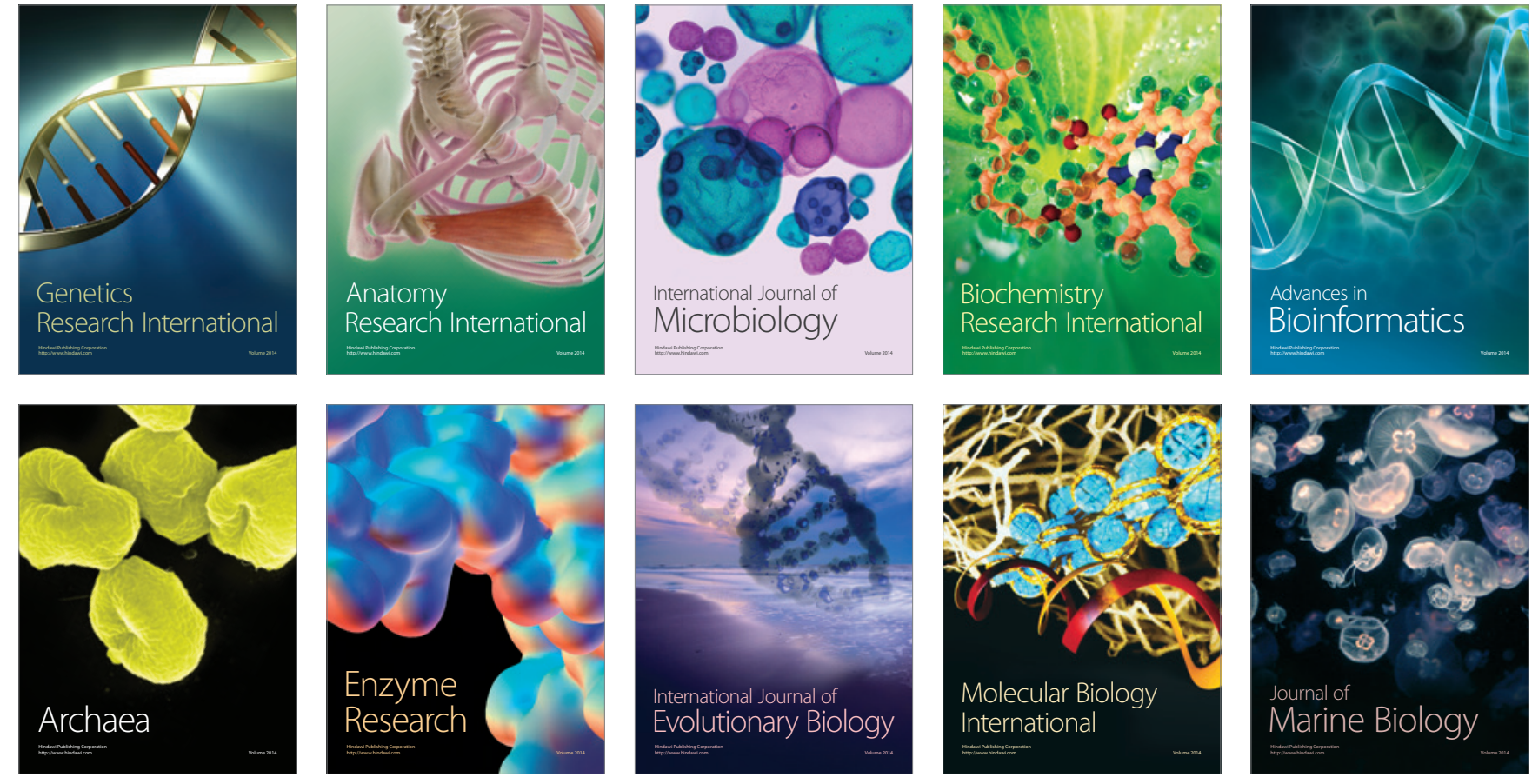